\title{
Extraocular Muscles and their Relationship to the Accessory Abducens Nucleus in rats as Studied by the Horseradish Peroxidase Method
}

\author{
By \\ YotaRo ODA \\ Department of Anatomy, School of Medicine, Keio University, \\ Shinjuku-ku, Tokyo 160, Japan \\ -Received for Publication, December 19, 1980-
}

\begin{abstract}
Key words: Extraocular muscles, Accessory abducens nucleus, Rat, HRP.
Summary : 1) Studies were made of the accessory abducens nucleus and its relationship to the extraocular muscles besides the retractor bulbi muscles in the rat.

2) All the extraocular muscles had nerve fiber connections from the accessory abducens nucleus besides the retractor bulbi muscles.

3) The relationship between the accessory facial nucleus and accessory abducens nucleus was investigated. The accessory facial nucleus was located from dorsal of the principal facial nucleus to the medial proximal part of the descending part of the facial root fibers, while the accessory abducens nucleus was located from the medial distal part to the descending part of the facial root fibers.
\end{abstract}

Hutson et al. ('79) recently reported the existence of the accessory abducens nucleus as demonstrated experimentally by placing HRP flakes directly onto the cut stumps of nerves, and distinguished the accessory abducens nucleus from the accessory facial nucleus in the cat. Grant et al. ('79) found that motoneurons innervating the retractor bulbi muscle in the cat were of the accessory abducens nucleus by retrograde labeling and intracellular staining with HRP, and also by electrophysiological techniques.

After Held (1893) reported the existence of the accessory abducens nucleus, various papers on this nucleus were published by Lugaro (1894, in the rabbit), Pacetti (1896, in man), van Gehuchten (1898, 1906, 1908 in the rabbit), Kaplan and Finkelnburg
('00, in man), Tsuchida ('08, in man), Cajal ('09, in the mouse), Obsteiner ('12, in man), Terni ('22, in the mouse), Preziuso ('24, in the mouse, sheep, rabbit and cat), Shanner ('33, in the pig), and Kimmel (' 40 , in the rabbit). However, the nucleus was considered to be the accessory facial nucleus by Giannuli (1897, in man), Siemerling and Boedeker (1897, in man), Marinesco (1908, in the dog), Bach (1899, in man), Jacobson ('09, in man), van Valkenberg ('10, in man), Ariëns-Kappers ('10, in man; '12, in the seal and dog), Sterzi ('15, in man), Nakamura ('30, in' 51 mammals), Riley ('43, in man), van Buskirk ('45, in man) and Pearson ('46, in man. During our previous investigations on the nerve centers of extrinsic ocular muscles using HRP [Oda et al. ('77, 
'78 in rats)], the author studied the existence of the accessory abducens nucleus in the rat.

\section{Materials and Methods}

A total of 173 four- to five-week-old $(80-120 \mathrm{~g})$ Wistar rats was used in this study. The initial experiment was performed in 142 rats. The left extraocular muscles of the other anesthetized rats were chosen and dissected out under a Konan operating microscope. The muscles used were the levator palpebrae superioris, superior rectus, medial rectus, inferior oblique, inferior rectus, superior oblique, lateral rectus, retractor bulbi and left digastric. These muscles were injected with 300 units of a freshly prepared $30-40 \%$ solution of HRP (Sigma, type VI, lot Nos. 25C-9570, 26C-9580, 117-

Table 1. Numbers of experimenal rats

\begin{tabular}{lc}
\hline Muscle & No. of rats \\
\hline Levator palpebrae & 17 \\
superioris & 15 \\
Superior rectus & 15 \\
Medial rectus & 24 \\
Inferior oblique & 20 \\
Inferior rectus & 27 \\
Superior oblique & 24 \\
Lateral rectus & 20 \\
Retractor bulbi & 11 \\
Digastric & 173 \\
\hline
\end{tabular}

C-9570-1, and for digastric muscles, 59C$9560,20 \mathrm{~F}-9600)$ in $0.1 \mathrm{M}$ phosphate buffer ( $\mathrm{pH} 7.4$ ) or distilled water, using a $10 \mu \mathrm{l}$ Hamilton microsyringe and 33 gauge needle. At withdrawl of the needle, surgical cement, Alonalpha A (Sankyo Co., Tokyo), was applied around the injected site in the muscle to prevent leakage of the HRP and to prevent the neighboring tissues from being affected. After a survival time of $24-48 \mathrm{~h}$, the animals were anesthetized deeply with ether and perfused with saline solution and $0.1 \%$ paraformaldehyde-1.25\% glutaraldehyde- $1 \%$ sucrose in $0.1 \mathrm{M}$ phosphate buffer ( $\mathrm{pH} 7.4$ ). The removed brains were placed in fresh fixative solution overnight at $4^{\circ} \mathrm{C}$ and then left to sink in $25 \%$ sucrose in $0.1 \mathrm{M}$ phosphate buffer $(\mathrm{pH} 7.4)$ at $4^{\circ} \mathrm{C}$. Serial frozen sections of $40 \mu \mathrm{m}$ in thickness were cut frontally or horizontally. The histochemical procedures used were those of Graham and Karnovsky ('66) or Streit and Reubi ('77). The sections were lightly counterstained with thionine. Studies using HRP were also made in the same manner as above on rat left digastric muscles to distinguish the accessory abducens nucleus from the accessory facial nucleus.

\section{Results}

Normal anatomy: The author studied normal examples of the accessory abducens nucleus and accessory facial nucleus in Wistar rats since they had seldom been investigated previously [Nakamura ('30), Zeman and Innes ('63), König and Klippel ('63), Nishi ('65), Sherwood and Timiras ('70), and Glicksman ('80)]. The accessory abducens nucleus measured 400-

Table 2. Percentages of HRP positive neurons in the ipsilateral accessory abducens nucleus.

\begin{tabular}{lc}
\hline Muscle & $\begin{array}{c}\text { HRP positive } \\
\text { neurons }\end{array}$ \\
\hline Levator palpebrae superioris & $8.77 \%$ \\
Superior rectus & $14.03 \%$ \\
Medial rectus & $21.05 \%$ \\
Inferior oblique & $(2.19 \%)$ \\
Inferior rectus & $14.47 \%$ \\
Superior oblique & $(0.43 \%)$ \\
Lateral rectus & $19.73 \%$ \\
Rectractor balbi & $19.29 \%$ \\
\hline
\end{tabular}

(Note) Figures in paretheses are those where neurons were stained only lightly. 
$500 \mu \mathrm{m}$ in length and $200 \mu \mathrm{m}$ in width and height. The group comprised $53-80$ neurons (average 78 multipolar neurons) which were $20-40 \mu \mathrm{m}$ in diameter. The accessory facial nucleus is formed by two groups [Matsuda et al. ('77)]. The groups consisted of 124-144 neurons (average 131 neurons) which included both large-sized (16.5-25 $\mu \mathrm{m})$ multipolar neurons and spindle-shaped (12-28 $\mu \mathrm{m})$ neurons.

Experimental findings: The numbers of animals used in this study are shown in Table 1. All of the muscles besides the retractor bulbi, showed HRP positive neurons in the ispilateral accessory abducens nucleus which lies medial to the lower part of the facial root fibers. There were some differences in numbers of labeled neurons and in stainability (Figs. 7 and 8). For the oblique muscles, the neurons in the accessory abducens nucleus showed a rather poor ability to react and there were fewer numbers of labeled neurons (Figs. 7 and 8 and Table 2).

In the HRP injected digastric muscles, HRP labeled neurons were observed in the principal facial nucleus and accessory facial nucleus (Figs. 9-18) which lies dorsal to the principal facial nucleus and medial to the descending part of the facial root fibers of the upper part.

\section{Discussion}

Detailed studies on the identification of the accessory abducens nucleus, accessory facial nucleus and posterior trigemini have been reported by Hutson et al. ('79, in the cat). These nuclei clearly exist in the cat. In the rat, Nishi ('65) described the accessory facial nucleus, and his illutrations and written account appear to represent a different group of neurons from the accessory facial nucleus of Matsuda et al. ('77) and the present author. According to Matsuda et al. ('77), the accessory facial nucleus is formed by two groups, an inner descending part of the root fibers and a dorsal part of the facial nucleus, and they did not describe the existence of HRP labeled neurons in Nishi's area of the accessory facial nucleus which lies rostral to the descending part of the facial root fibers. The author found one lightly stained neuron in the area which Nishi described as "rostral to the descending part of the facial root fibers" (Fig. 19). Glicksman ('80) stated in his report on HRP studies of the rat lateral rectus that "three labeled cells were found in the ipsilateral accessory abducens" but he considered that "this may be due to uptake by the retractor bulbi muscles". His careful manner of expression appears to reflect a small number of experimental cases. However, Grant et al. ('79) reported the same observations in the cat. In this study, as reported previously [Oda et al. $(77,78)$ in the rat], there could be no leakage of HRP from the injected extrinsic ocular muscles because of the distinct localization of the lower motor centers in the oculomotor nucleus, and during the above study, the author often found labeled neurons in the accessory abducens nucleus. Additional studies to the above indicate that there were nerve fiber connections between the extraocular muscles besides the retractor bulbi muscles based on retrograde transport of HRP in the rat. There were two large populations of labeled neurons composing the lateral rectus and medial rectus (Table 2). The interesting fact is that they represent antagonistic muscles. However, it is rather difficult to give a definite localization for motor neurons of the extrnsic ocular muscles in the accessory abducens nucleus.

To differentiate the accessory abducens nucleus from the accessory facial nucleus, the author injected HRP into the digastric muscles of aats and found positively labeled neurons in the ipsilateral facial 
nucleus and the accessory facial nucleus which lie dorsal to the principal facial nucleus. Its relationship to the accessory abducens and principal facial nucleus is illustrated in Fig. 20.

\section{Acknowledgements}

The author greatly appreciates the invaluable help and encouragement of Prof. K. Shimai of the Department of Anatomy, School of Medicine, Keio University, and Prof. T. Suzuki of the Department of Veterinary-Anatomy, Tokyo Noko Daigaku.

\section{References}

1) Ariëns-Kappers, C. U. (1910) Further Contributions on Neurobiotaxis: V. The migration of the motor cells of the bulbar trigeminus, abducens and facialis in the series of vertebrates and the differences in the course of their root fibers. Verhand. d. Kon. Akad. V. Wetenschappen te Amsterdam. Tweedie sectie. Deel XVI, No. 4. (citied by Hutson)

2) Ariëns-Kappers, C. U. (1912) Weitere Mitteilungen über Neurobiotaxis: VII. Die phylogenetische Entwicklung der motorischee Wurzelkerne in Oblongata und Mittelhirn. Folia neurobilo., Band 6, Sommer Erganzungscheft. (cited by Hutson)

3) Bach, L. (1899) Zur Lehre von den Augenmuskellähmungen und Störungen der Pupillenbewegung. Graefes Archv für ophthalmologie, S. 622: 553-630.

4) van Buskirk, C. (1949) The seventh nerve complex. J. Comp. Neur., $82: 303-$ 333.

5) y Cajal, R. (1909) Histologie du Systéme Nerveux de 1'Homme et des Vertebres. A. Maloine, Paris, France. (cited by Nakamura)

6) Giannuli, F. (1899) Contibuto allo studio clinico ed anatomico della neningite sifilitca cerebro-spinale. Riv. sperim, di freniatria, Vol. $13: 840-869$.

7) van Gehuchten, A. (1898) Anatomie du System Nerveux de 1'Homme. First ed.
Trois Rois, Louvain. Recherches sur l'origine réelle des nerf craniens. I. Les nerfs moteurs oculaires. J. de Neur., 3 : 114-129.

8) van Gehuchten. A. (1906) Le System Nerveux de 1'Homme. Fourth ed. Troes Rois, Louvain. (cited by Hutson)

9) van Gehuchten. A. (1908) Les Centres Nervux. Louvain. (cited by Hutson)

10) Glicksman. M. A. (1980) Localization of motoneurons controlling the extra ocular muscles of the Rat. Brain Res., 188: 5362.

11) Grant, K., Gueritaud, J. P., HorcholleBossavit, G. and Tyc-Dumont (1979) Anatomical and Electrophysiological Identification of Motoneurons Supplying the Cat Retactor Bulbi Muscle. Exp. Brain Res., 34 : 541-550.

12) Graham, R.C. Jr. and Karnovsky, M. J. (1966) The early stages of absorbtion of injected horseradish peroxidase in the proximal tubules of mouse kidney : Ultrastructural cytochemistry by a new technique. J. Hirstchem. Cytochem., $14: 291-$ 302.

13) Held, H. (1893) Beitrage zur feineren Anatomie des Kleinhirns und des Hirnstammes. Arch. f. Anatomie und Physiologie. Anat. Abt., s. $438:$ 435-446.

14) Hutson, K.K., K. K. Glending and R.B. Masterson (1979) Accessory Abducens Nucleus and Its Relationship to the Accessory Facial and Posterior Trigemini Nuclein Cat. J. Comp. Neur., $188: 1-16$.

15) Jacobsohn, L. (1909) Uber die Kerne des menschlichen Hirnstammes. Anhang Abh. Kon. Preuss. Akad. wiss., Physik.Math. Cl., pp. 1-70. (cited by Hutson)

16) Kaplan, L. and Finkenlnburg, R. (1900) Beitrage zur Kenntnis des sogenannten ventralen Abducenskerns. Arch. f. Psych., Bd. 33 : 965-972.

17) Kimmel, D.L. (1940) Differentiation of the bulbar motor nuclei and the coincident development of associated root fibers in the rabbits. J. Comp. Neur., 72:83148.

18) Lugaro, E. (1894) Sull'origine di alcuni nervi encepfalicii (V, VI, VII). Arch di ottalmologin, Vol. 2: 181-186. (cited by 
Hutson)

19) Marinesco, G. (1898) L'Origine du facial superieur. Rev. Neur., T. VI : 30-33.

20) Matsuda, K., Uemura, M., Kume, M., Matsushita, R., Sato, M., Ito, K., Mizuno, N., and Konishi, A. (1977) A comparative anatomical study of the digastric motoneurons by means of horsradish peroxidase (HRP) method. Acta Anatomica Nipponica., $52:$ 40-41.

21) Nakamura, T. (1930) Vergleichend anatomische Untersuchungen über den songenannten Akzessorischen Abduzenkern. Arb. nerol. Inst. Uiv. Wien, 32: 262-282.

22) Nishi, M. (1965) The intramedullary course of the facial nerve and the facial, accessory facial and abducens nucleus of several mammals. Okajima Fol. ant. jap., 4 : 233-265.

23) Obersteiner, (1912) Anleitung beim Studium des Baues der nervösen Zentralorgane im gesunden und Kranken Zustande. 5 Aufl., S 531. (cited by Nakamura)

24) Oda, Y., Inoue, Y., Shimai, K. and Suzu$\mathrm{ki}, \mathrm{T}$. (1977) The nerve centers of the extrinsic ocular muscles. Acta Anatomica Nipponica, 52 : 18.

25) Oda, Y., Inoue, Y., Shimai, K. and Suzuki, T. (1978) The nerve center of the rat extrinsic ocular muscles. Acta Anatomica Nipponica, $53: 54$.

26) Pacetti, G. (1896) Sopra il nucleo di origine del nervus abducens. Ric. f. nel. laboratorio d'Anat. norm. di Roma 5 : 121-133.

27) Pearson, A. A. (1946) The development of the motor nuclei of the facial nerve in man. J. Com. Neur., 85 : 461-476.

28) Preziuso, L. (1924) Sul nucleo accessorio del nervo abducente in alcuni uccelli e mammiferi. Nuovo Ercolani, 29 : 1-22.

29) Riley, H. A. (1943) An Atlas of the Basal Ganglia Brain Stem and Spinal Cord. Williams and Wilkins, Baltimore, Maryland.

30) Shanner, R.F. (1933) The development of an accessory abducens nucleus in the pig. Anat. Rec., 55: 36 .

31) Siemerling, E. and Boedeker, J. (1897) Chronische fortschreitende Augenmuskellähmung und progressive Parelyse. Arch. fur Psychiatrie, Bd., 29 : 716-767.

32) Streit, P. and Reubi, J. C. (1977) A new and sensitive staining method for axonally transported horseradish peroxidase (HRP) in the pigeon visual system. Brain Res., 126: 530-537.

33) Sterzi, G. (1915) Anatomia del sistema nervoso centrale dell'uomo. ed. Padova.

34) Terni, T. (1922) Sul nucleo accessorio d'origine del nervo abducente nei retti. Monit. zool. ital., 32: 67-76.

35) Tsuchida, U. (1906) Über Ursprungskerne der Augen bewegungsnerven. Arb. aus dem hirnanat. Institut der Zürich, 2 : 1-206. 


\title{
Explanation of figures
}

\author{
Abbreviations \\ VI, principal nucleus of the abducens. \\ VII, principal nucleus of the facial. \\ dVII, descending part of the facial root fibers. \\ Acc VI, accessory abducens nucleus. \\ Acc VII, accessory facial nucleus.
}

\section{Plate I}

HRP labeled neurons in the accessory abducens nucleus after injection into the following muscles :

Fig. 1. The retractor bulbi muscle. $\times 100$.

Fig. 2. The levator palpebrae superioris. $\times 100$.

Fig. 3. The superior rectus. $\times 100$.

Fig. 4. The medial rectus. $\times 100$.

Fig. 5. The inferior rectus. $\times 100$.

Fig. 6. The inferior oblique. $\times 100$.

Fig. 7. The lateral rectus. $\times 100$.

Fig. 8. The superior oblique. $\times 100$.

(Figs. 1-8 are all frontal sections.) 

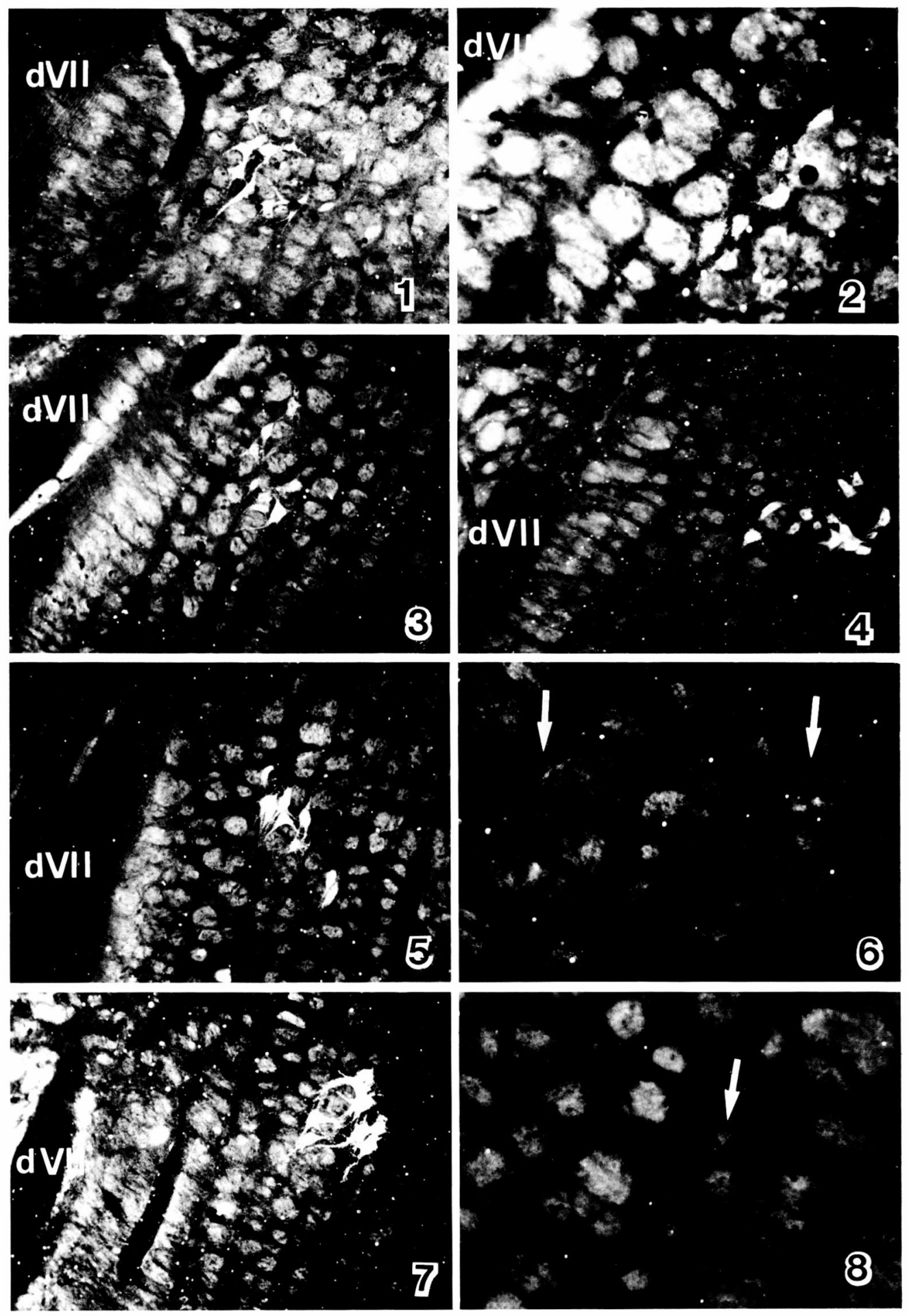

Y. Oda 


\section{Plate II}

Studies of the accessory facial nucleus. HRP was injected into the left digastric muscles.

Figs. 9-15. Frontal sections. $\times 100$. From caudal to rostral.

Fig. 16. Horizontal section. $\times 100$. Rostral to left and cauda to right. 

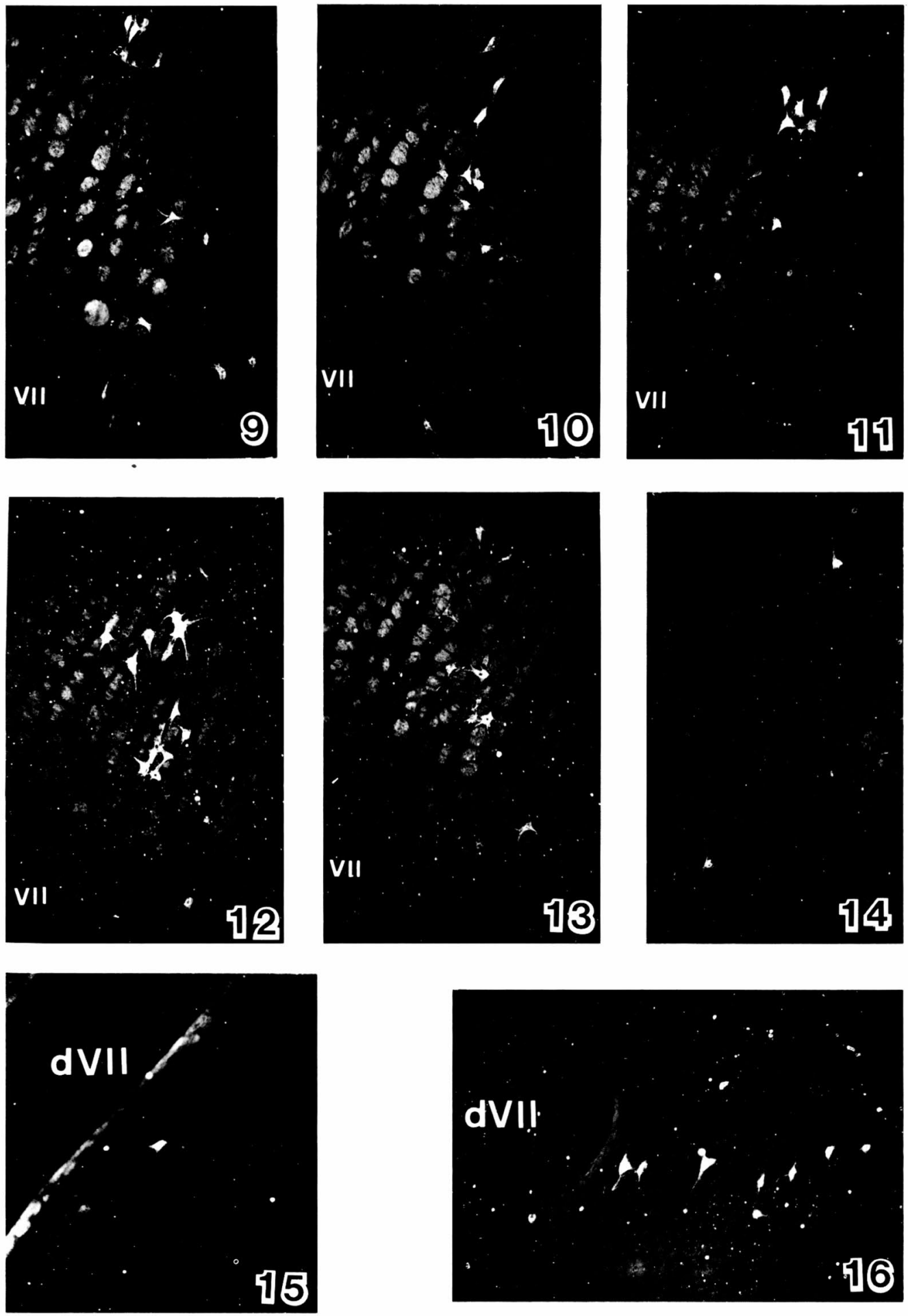

Y. Oda 


\section{Plate III}

Figs. 17 and 18. Sagittal sections. $\times 100$. Rostral to left and caudal to right.

Fig. 19. The arrow indicates a slightly stained neuron located rostral to the descending part of the facial root fibers. $\times 250$. Rostral to left and caudal to right.

Fig. 20. Schema of the accessory abducens nucleus and the accessory facial nucleus. 



Caudal 